\section{Strangers in a strange land: Egyptians in southern Palestine during the Bronze Age Rachael Sparks}

When the Institute of Archaeology was formally established in 1937, it became responsible for housing Sir Flinders Petrie's collection of archaeological material from Palestine. ${ }^{1}$ This unique inheritance has great value as a research collection, as its curator demonstrates here in her discussion of interaction between Egypt and Palestine in the Bronze Age.

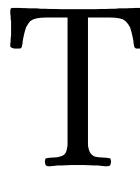

he eminent archaeologist and first holder of the Edwards Chair of Egyptology at UCL, Sir Flinders Petrie, is best known for his work in Egypt. However, he devoted the last 15 years of his life to digging in southern Palestine, which he euphemistically described as "Egypt over the border". Although he may have used this phrase partly to persuade supporters, such as the British School of Archaeology in Egypt, to continue funding his projects, it was no idle comment. Indeed, one of the main characteristics of the three sites in Palestine that Petrie chose to excavate was that they lay in a frontier zone at the southern edge of the land of the Canaanites. ${ }^{2}$ Farther south, the more arid lands of Sinai and the Negev inhibited the development of urban centres and were home to groups with a pastoral way of life, such as the shashu - the bedouin of the Bronze Age and beyond that region were the borders of Egypt itself.

\section{The Petrie Palestinian Collection}

Many thousands of objects were left to the Institute of Archaeology by Petrie, as a legacy of his passion for the past and to be used in training the archaeologists of the future. ${ }^{3}$ They came from a few sites strung out along the Wadi Ghazzeh in southern

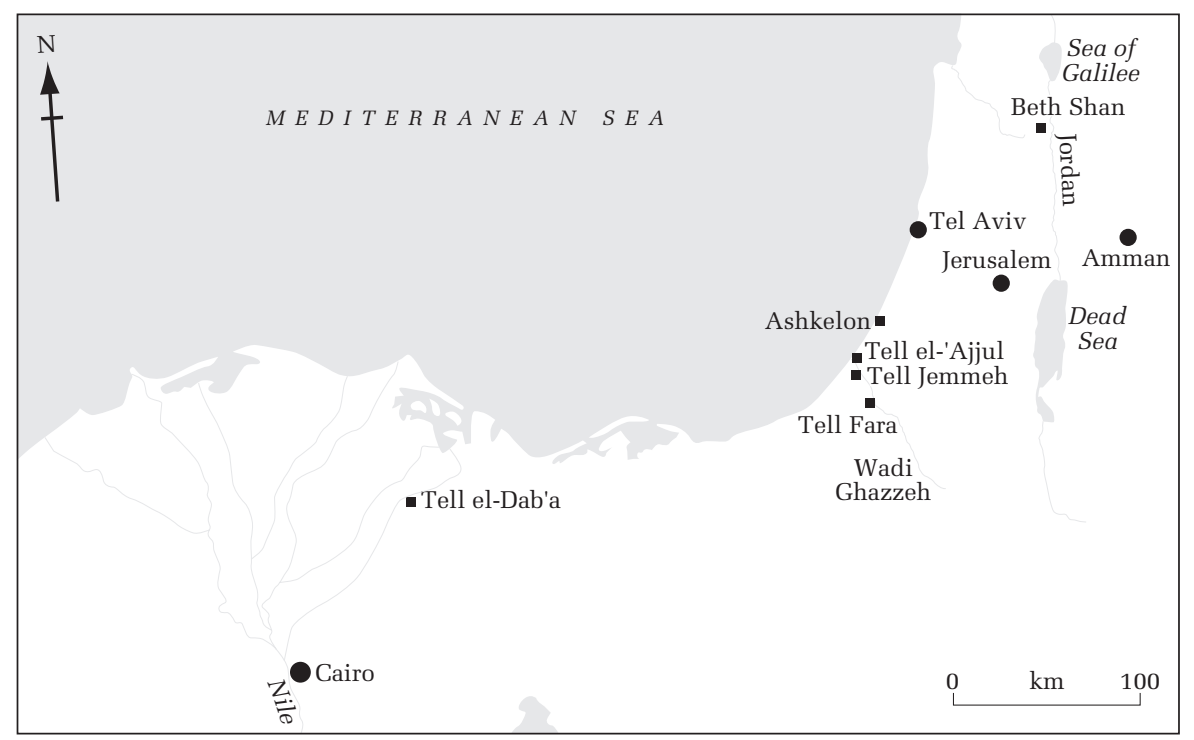

Figure 1 The Levant and the Nile delta, showing the location of the ancient sites men-

tioned in the text.

Palestine, principally the ancient towns of Tell el-'Ajjul, Tell Fara and Tell Jemmeh (Fig. 1). They range in age mainly from the third to the first millennium BC, and almost every material and class of artefact is present: ceramic vessels, stone and metal tools and weapons, figurines, seals, amulets, jewellery and a wide variety of personal items.

A project is currently under way to document the collection fully, and to enter onto a database images and details of every object. The database will then be made available through the Internet to researchers around the globe. In the course of this work, fresh evidence has come to light that illuminates the cross-cultural relationships that existed between Egypt and the Levant during the Bronze Age. My own research, part of which is described here, focuses on how different categories of material - administrative, domestic and religious - can be used to explore the social and technological interchanges that made up the complex web of Bronze Age societies in the two regions.

\section{Life on the edge of empires}

The overland caravan and military route across the frontier zone between Egypt and southern Palestine was an historical hotspot, and the peoples living there often found themselves at an interface between different and sometimes conflicting cultures. In the Middle Bronze Age (20001540 BC), increasing economic exploitation of resources in Sinai by the Egyptians, as well as the development of trading centres such as Tell el-Dab'a in the eastern Nile delta (Fig. 1), saw waves of Canaanite immigrants drawn south. These settlers gradually rose to social and political prominence in their new communities in Egypt, until their leaders were able to assume the ultimate accolade - that of becoming pharaoh. Known as the Hyksos, a word derived from an Egyptian phrase that translates as "rulers of a foreign land", they absorbed much Egyptian culture in their rise to power. In turn, their cousins back in Canaan were at the receiving end of new products and styles, as trade flourished between the two neighbouring regions.

In Egypt, this process of infiltration and acculturation is detectable in the textual and archaeological records. ${ }^{4}$ People with semitic names appear in Egyptian documents, in a variety of occupations ranging from shopkeeper to temple songstress. Objects of Canaanite style and manufacture also appear at contemporary sites in Egypt, although most of this evidence comes from the north of the country where the Hyksos rulers had their strongholds. Many such objects are to be found in the collection of the Petrie Museum of Egyptian Archaeology, also housed at University College London. ${ }^{5}$ At the same time, a similar process was happening back in southern Palestine. Egyptians and Egyptianized Canaanites came to live in the cities of the Levant, to facilitate the commercial and diplomatic ties that were developing between the regions. Nor did these people come empty handed. Merchants, mercenaries and artisans, entrepreneurs and opportunists, each would have brought with them a whole system of cultural values reflecting their background and upbringing. Some of these would find expression in the small, personal items they took with them to their new homes, such as perfume jars, cosmetic applicators, jewellery and amulets (Figs 2-4). Others would find expression in their daily lives - their diet and eating customs, the shrines they worshipped at, or the tools they used to carry out their trades. All these things leave their mark on the archaeological record, and each has its own story to tell.

These processes of interaction did not stop at this stage, and the subsequent history of southern Palestine reflects its continuing role as a frontier zone. The Egyptian rulers of the Seventeenth Dynasty (1638-1540 BC) - who became vassals of the Hyksos - seem to have been involved in several confrontations with their overlords. Sekenenre Tao died of a wound inflicted by an Asiatic-style battle axe, and his successor Kamose broke a treaty by raiding settlements controlled by the Hyksos in Middle Egypt and the Nile delta. 


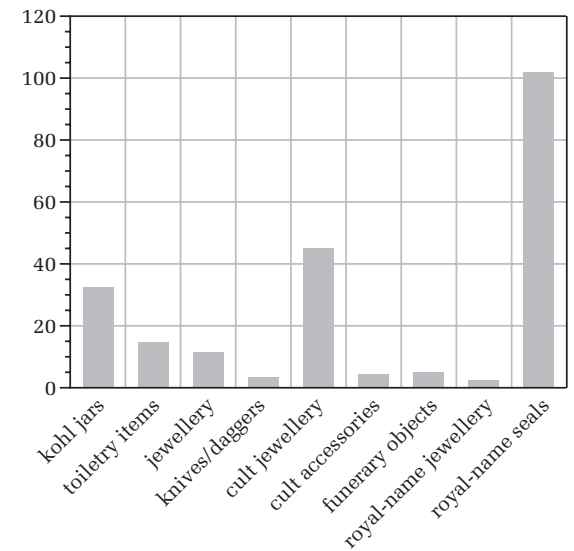

Figure 2 The frequency of selected classes of Egyptian material found at Tell el-'Ajjul, dating to the Middle and Late Bronze Age. Toiletry items include mirrors, cosmetic applicators and razors; jewellery consists of amulets, and finger rings bearing divine names; cult accessories consist of figurines and musical instruments; funerary objects include shabtis (human figures) and fragments of canopic jars.

After his death, his brother Ahmose continued the fight, capturing their capital city at Avaris (modern Tell el-Dab'a) and forcing the Hyksos to retreat into southern Palestine, where their dynasty was finally brought to an end by the pursuing army of the Egyptians. In the following period, Egypt took a much more aggressive military stance towards Canaan that culminated in conquest and absorption into the powerful Egyptian empire of the New Kingdom (1540-1070 BC; Fig. 5).

The land route between Egypt and southern Palestine became crucial in this process. It had long had some value for the passage of trade caravans, linking the economies of the two regions. However, in the new world order that followed the conquest of Palestine, it also became part of a wider communications network, known as the Ways of Horus, used by both military and civilian organizations. Forts and waystations were set up along the route, to safeguard supplies and water sources along it. It became a conduit for the swift passage of armies (sometimes as many as $20,000 \mathrm{men}$ ), as well as royal messengers and diplomats. From this time, more and more Egyptian personnel came to be stationed in Canaan, bringing with them the apparatus of empire, including fresh technological and ideological concepts.

As a result, a new wave of architectural styles and types of object emerges, as Egyptian craftsmen and other specialists actually set up production centres in Canaan (Fig. 6). One consequence of this development is that we can sometimes distinguish between imports and objects made locally in Egyptian style only through scientific analysis of the materials from which they were made. It also becomes increasingly difficult in this period to distinguish between an Egyptian living in Canaan, and a Canaanite who has adopted Egyptian culture, as local elites used the trappings of their conquerors to identify with the new sources of political power.

At the close of the second millennium BC, the Egyptians withdrew from southern Palestine, but the region retained its strategic value. In the following centuries, it was contested by Philistines and Israelites, absorbed by the Assyrian, Neo-Babylonian and Persian empires, conquered by the armies of Alexander the Great, claimed by his generals, and then absorbed into the Roman empire. The region has continued to act as a border zone - whether a northern frontier of an Egyptian state or a southern boundary of a northern empire - right up to the present day. Yet throughout this troubled history its occupants have managed to survive the processes of change by taking on foreign ideas and technologies and integrating them with their own distinctive material cultures.

(a)

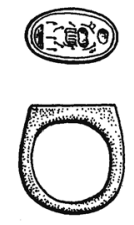

(b)

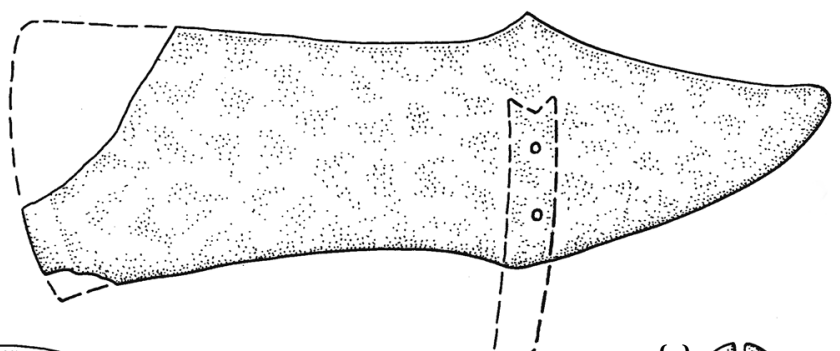

(d)

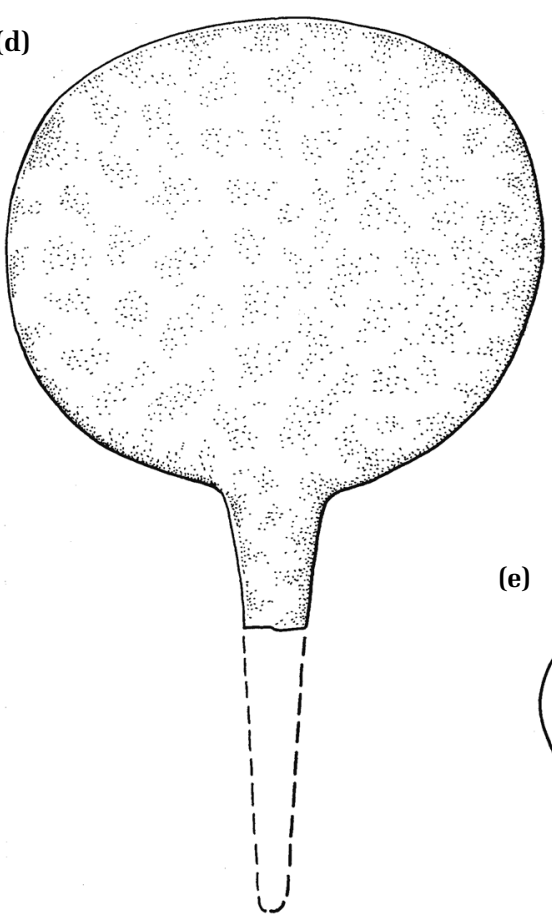

Objects as indicators of cultural identity

These dynamic processes of interaction between Egypt and southern Palestine, extending over millennia, are reflected in many objects in the Petrie Palestinian Collection. Two types of Egyptian artefact can be used to illustrate this phenomenon: stone cosmetic vessels and a specific type of metal razor.

During the Middle Bronze Age, Egyptian cosmetic vessels became popular items of trade with Palestine, reflecting the increasing sophistication of the Canaanites, as well as their entry into broader world markets. They were used to hold scented oils and fats, various kinds of make-up and some medicinal preparations. Yet Canaanite customers were selective in their choices. The range of vessels that appears in Palestine is not identical to Egyptian assemblages, but a smaller subset that reflects different cultural preferences. Some forms that are uncommon in Egypt,

Figure 3 (above) Egyptian toiletry accessories from Tell el-'Ajjul: (a) faience finger ring with the name of Tutankhanem, tomb 419 (Rockefeller Museum, no. 33.1708);(b) bronze mechak razor, tomb 418 (present location unknown); (c) bronze hair ring covered in gold leaf, tomb 1206 (British Museum no. 1949.2-12/26);(d) bronze mirror, tomb 1149 (Petrie Palestinian Collection, UCLInstitute of Archaeology no. EXIII.18/3);(e) kohl jar, tomb 257 (Petrie Palestinian Collection, no. EXIII.76/2); (f) bronze cosmetic applicator, tomb 1030 (present location unknown); (g) bronze combination razor and "wig curler" (Petrie's interpretation of the function of this object), area QP 1071 (Petrie Palestinian Collection, no. EXIII.36/5). 

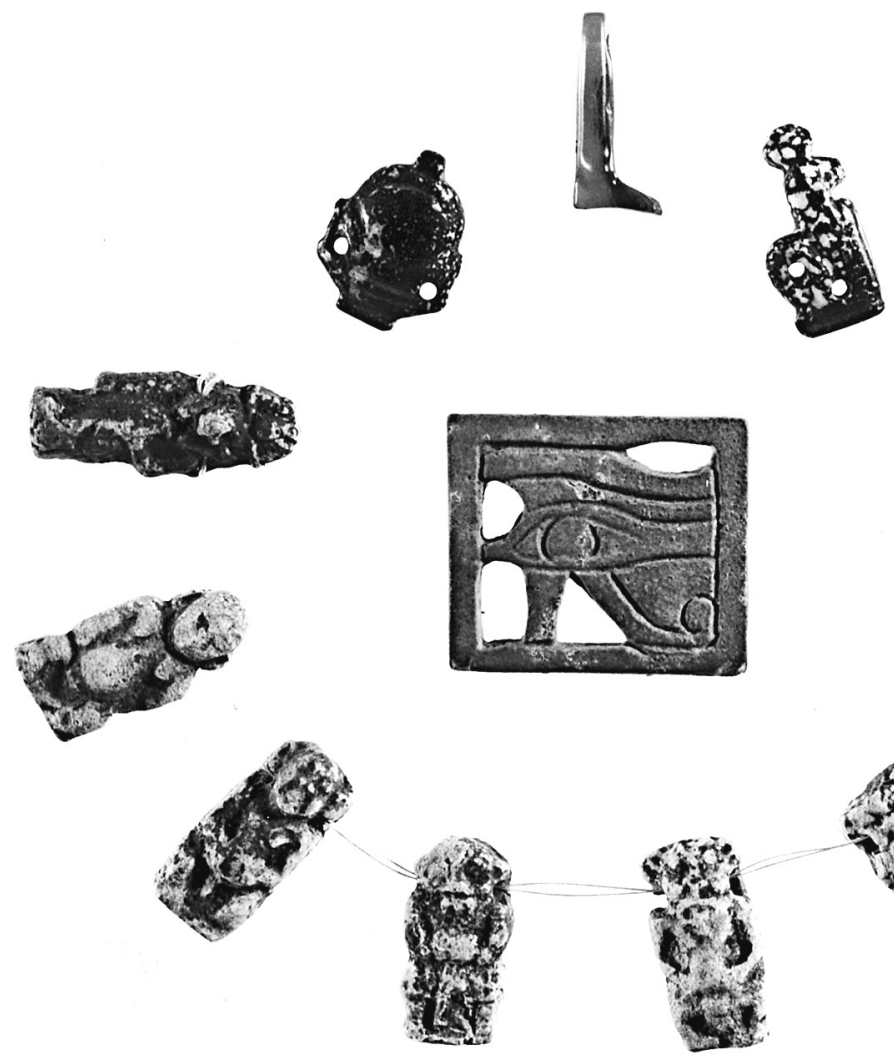

Figure 4 (right) Stone and faience amulets from the Petrie Palestinian Collection, UCL Institute of Archaeology: centre: eye of Horus, no. EXXXVI.16/10 (length $3.84 \mathrm{~cm}$ ); upper (left to right): nos EVI.64/ 13, EXIII.30/3 and EVI.64/12; lower: a string of eight Egyptian deities, no. EVI.17/3.

such as the juglet, were very popular. Other shapes were usually ignored, including the canopic jar and the hes vase. ${ }^{6}$ This is probably because these vessels were associated with particular Egyptian funerary and cult practices, and so they had no role in a Canaanite cultural setting.

The two most popular forms of cosmetic vessel in Egypt appear only sporadically in Canaan: an elegant concave-sided jar that was often used to make up sets of the seven sacred oils used in Egyptian burials, and a squat bell-shape jar (Fig. 3e) used to hold kohl, a type of eye make-up. I decided that the second type merited further investigation because it appeared to be an integral part of the Egyptian daily toilette, rather than a special type of object used in burial ritual. If Canaanites were reluctant to adopt the Egyptian kohl jar - perhaps because the contents had little role in Canaanite ideas of beauty - might its occa-

Figure 5 Egyptian relief from Karnak depicting the Egyptian army besieging the Canaanite city of Ashkelon (Fig. 1), dating to the reign of Merenptah (1213-1203 BC) a graphic representation of military confrontation between two cultures (modified from figure 3 in L. E. Stager (1985; see n. 9 below).
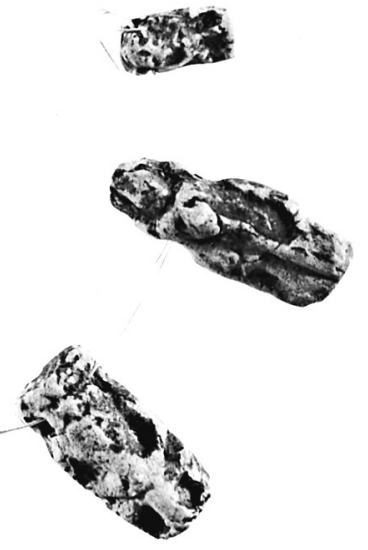

sional appearance be used either as an index of Egyptianization, or as an indicator of the presence of Egyptians themselves? A study of the distribution of kohl jars produced some interesting results.

First, the earliest versions of the kohl jar, which date to the Middle Kingdom (21161795 BC), do not appear in Palestine. This suggests that kohl jars were not imported until later; and indeed, the archaeological contexts in which they have been found in Palestine point to this taking place mostly during the Hyksos period or last phase of the Middle Bronze Age (c. 1638-1540 BC), when contact between the two areas was at a peak. Secondly, although kohl jars have been found sporadically across Palestine, there is a concentration of them at Tell el-'Ajjul, in the south: 31 of the total of 53 known examples were found here. Furthermore, some two thirds of these were recovered from settlement contexts, rather than tombs. Generally the reverse is true in the Levant, with Egyptian cosmetic vessels being a popular funerary or temple offering, and rarer in domestic surroundings. One possible interpretation is that the kohl jars found in Palestine represent the possessions of Egyptians working in the area, but that few found their way into contemporary tombs because most of their owners finished their tour of duty and returned home, leaving their unwanted possessions

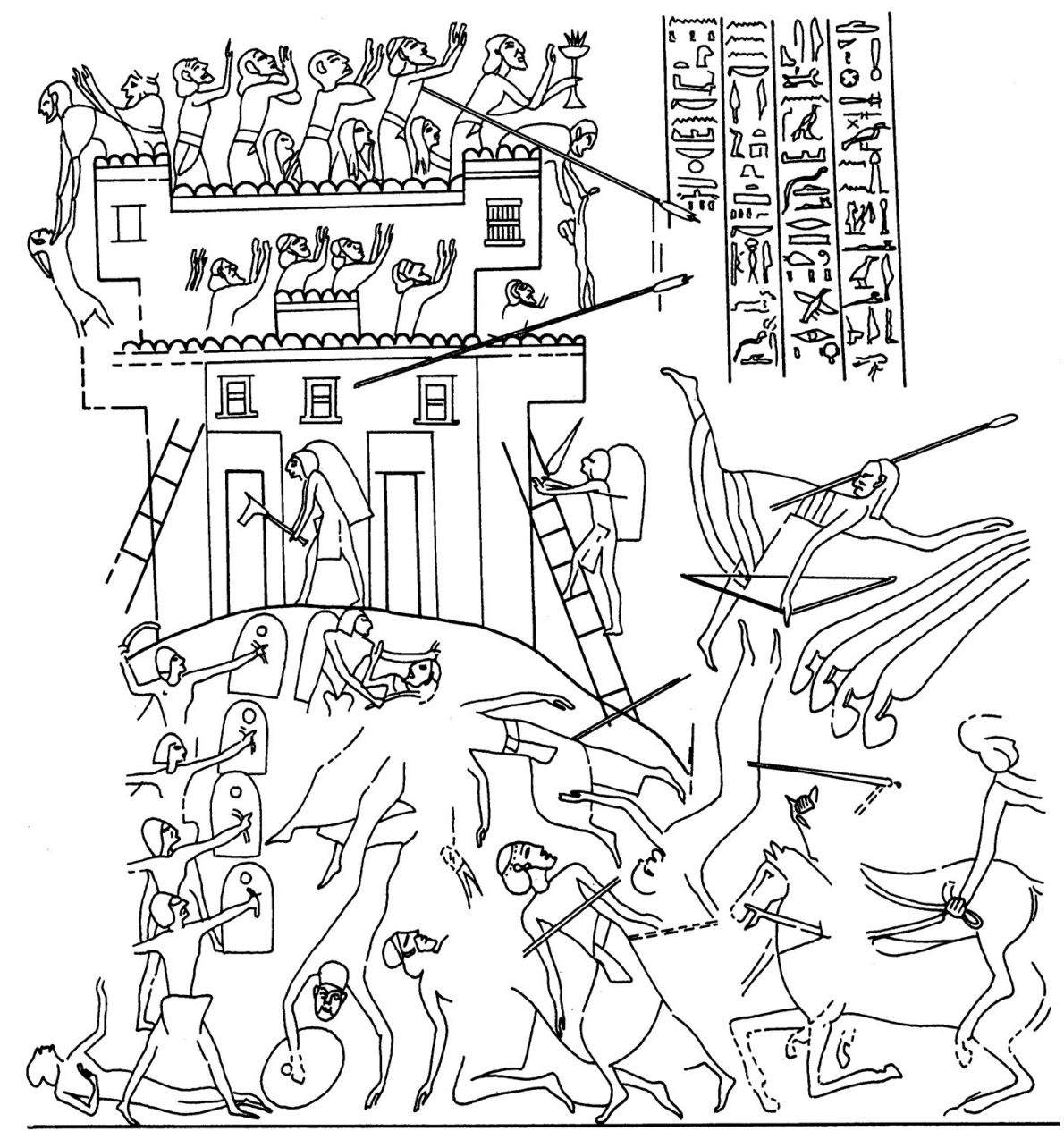




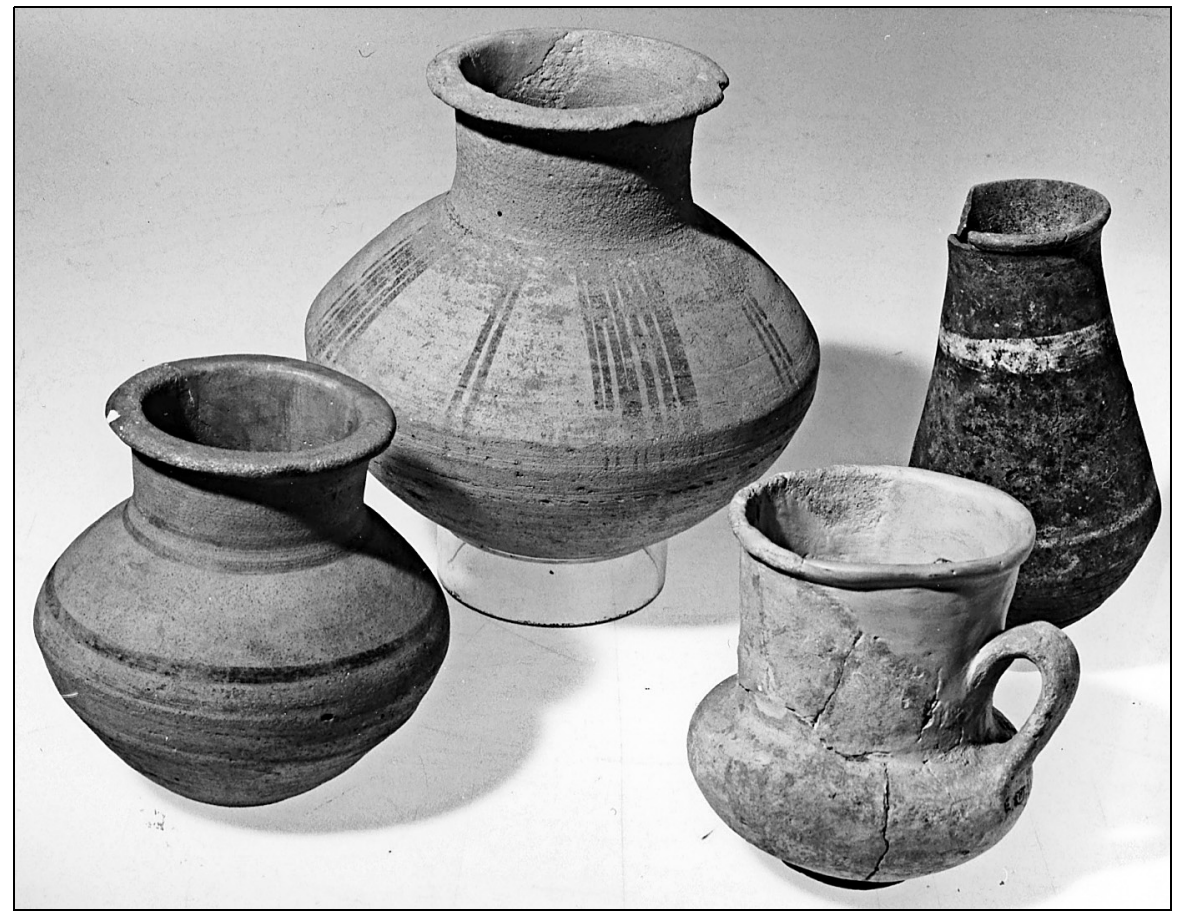

Figure 6 Egyptian-style pottery from the Petrie Palestinian Collection, UCL Institute of Archaeology, found at Tell el-'Ajjul and Tell Fara: left to right nos EXIII.112c/1, EXIII.67a/ 1, EXIII.2/3 and EVI.45/1. These vessels were either imported or made in the region by Egyptian potters using local clays; the tallest vessel is $18.5 \mathrm{~cm}$ high.

behind. Tell el-'Ajjul is notable in the Middle and early Late Bronze Age as a site with other concentrations of Egyptian-style goods, and it seems likely that this unusual quantity of Egyptian kohl jars is a part of the same phenomenon.

The second example of an Egyptian artefact found in southern Palestine is a distinctive tool, known as the mechak razor (Fig. 3b). It was often included among grave goods in Egypt during the reign of the pharaoh Tuthmosis III (1479-1425 BC), and was probably used to remove body hair as a means of expressing cleanliness and purity. ${ }^{7}$ Such razors are rare outside Egypt, but three were excavated at Tell el-'Ajjul in southern Palestine, where they were recovered from tombs. One of them was associated with six gold hair rings of Egyptian type, another with an Egyptian-style kohl applicator made of bronze. It was customary for Egyptian men to appear clean shaven, a preference that Canaanites did not share, so perhaps these finds represent ordinary possessions of Egyptians who had been working in the region. Part of a similar razor, which may have belonged to an Egyptian soldier, was also recovered from a burial in a clay sarcophagus at the Egyptian garrison site of Beth Shan (Fig. 1). The Egyptian character of the burial is further strengthened by the fact that it also contained a funerary figurine, known as a shabti, a type of object very rarely found outside Egypt. ${ }^{8}$

\section{Conclusion}

The Petrie Palestinian Collection is important to the Institute in several ways. It is a

\section{Notes}

1. For a brief account of the role of the Petrie Palestinian Collection in the founding of the Institute, see pp. 4-8 in J. D. Evans, "The first half-century - and after", Bulletin of the Institute of Archaeology 24, $1-25,1987$, and for a fuller discussion see pp. 356-64 in P. J. Ucko, "The biography of a collection: the Sir Flinders Petrie Palestinian Collection and the role of university museums", Museum Management and Curatorship 17, 351-99, 1998.

2. The Canaanites were the Bronze Age inhabitants of a region that approximately corresponds to modern Israel, Jordan, Lebanon and southern Syria. It contained several political states, whose boundaries fluctuated over time, as they fell under the control of various neighbouring or external powers. For a discussion of the origin and use of the term Canaanite, see A. F. Rainey, "Who is a Canaanite: a review of the textual evidence", Bulletin of the American Schools of Oriental Research 304, 1-15, 1996

3. See Ucko (1998: $n .1$ above).

4. R. T. Sparks, "Canaan in Egypt: archaeological evidence for a social phenomenon", forthcoming in J. Bourriau, J. Phillips, L. Smith (eds), The social context of technological change, II: Egypt, the Aegean and the Near East, 1650-1150 BC (Oxford: Oxbow).

5. An article by S. MacDonald, R. McKeown and S. Quirke on the scope of the collections held in the Petrie Museum of Egyptian Archaeology at UCL and on initiatives being taken to make it more accessible to the public appeared on pp. 57-50 of Archaeology International 2000/ 2001.

6. Canopic jars are vessels that were used to house the embalmed internal organs of the deceased: stomach, intestines, lungs and liver. They were an essential item of funerary equipment and were manufactured in sets of four, each jar provided with a lid representing various protective deities. Hes vases were tall, slender ritual vessels that were used for pouring funerary libations.

7. For further details on this type of object, see K. O. Eriksson, "A close shave: the new evidence for chronology of Egyptian New Kingdom mechak razors found in Late Cypriot I tombs in northwestern Cyprus", pp. 183-99 in P. M. Fischer (ed.), Contributions to the archaeology and history of the Bronze and Iron Ages in the eastern Mediterranean: studies in honour of Paul Aström (Vienna: Österreichisches Archäologisches Institut, 2001).

8. See p. 220 in C. R. Higginbotham, Egyptianization and elite emulation in Ramesside Palestine: governance and accommodation on the imperial periphery (Leiden: E. J. Brill, 2000).

9. L. E. Stager, "Merenptah, Israel and Sea Peoples: new light on an old relief", Eretz Israel 18, 56*-64* 1985. 